\title{
INFECTIOUS MONONUCLEOSIS AND AUTOIMMUNE HEPATITIS
}

\author{
Skoric Jasmina, Pavkovic Bojan \\ Health Centre "Dr Simo Milošević", Belgrade, Serbia
}

Primljen/Received 02. 03. 2021. god.

Abstract: Introduction: The case report shows a sick nine-year-old girl whose disease initially manifested as infectious mononucleosis. Encountering infectious mononucleosis in pediatrics is quite common and it is estimated that as much as $50 \%$ of children are infected with the Epstein-Barr virus before the age of 5. Suspicion of mononucleosis emerges every time there is a patient with swollen neck lymph nodes, fever, painful and difficult swallowing. However, the laboratory findings in the second month of the onset of the disease raised suspicion for autoimmune disease.

Case report: Based on the clinical manifestations, the patient underwent a series of examinations such as biochemical analyses, blood count, and Epstein-Barr virus serology, as well as abdominal ultrasound and testing of ceruloplasmin and Alpha-1 antitrypsin values. The autoimmune disorder was confirmed after detecting elevated IgG levels, the presence of anti-LKM antibodies, and interface hepatitis as a pathoanatomic substrate of liver bioptates.

Conclusion: The case report presents the Epstein-Barr virus as a direct trigger of autoimmune hepatitis. This DNA virus known for its cytopathic effect on B lymphocytes induced the swelling of lymph nodes, liver, and spleen. Its overall impact on B lymphocytes and the liver led to producing specific autoantibodies and infiltrating hepatic nodes with lymphocytes.

Key words: antibodies, hepatitis, biopsy, Epstein-Barr virus.

\section{INTRODUCTION}

Infectious mononucleosis is an acute, viral disease caused by the Epstein-Barr virus (EBV), a member of the herpes virus family. Transmission occurs by a fecal-oral route with an incubation period of 30-50 days. The infection is often asymptomatic or is encountered as pharyngitis with clinical characteristics in the forms of exudative tonsillitis and cervical lymphadenopathy. An enlarged liver and spleen can be found in $75 \%$ of
Prihvaćen/Accepted 10. 04. 2021. god.

patients, as well as elevated transaminase levels. In a smaller number of patients, a maculopapular rash can also occur, as well as urticaria, petechiae, or scarlet fever. Characteristic hematologic findings are absolute lymphocytosis and atypical lymphocytes that last 2-3 weeks. The diagnosis is confirmed with the use of the Paul-Bunnell-Davidsohn test that examines Immunoglobulin $\mathrm{G}(\operatorname{IgG})$ antibodies and heterophile antibodies $(1,2)$. Epstein-Barr virus infections frequently affect the liver and cause hepatitis. Infectious triggers are often associated with certain autoimmune diseases whereby EBV is well-known for being the causative agent. Numerous reports are showing evidence of autoimmune hepatitis (AIH) following the EBV infection (3). AIH is a chronic liver disease which, if untreated, can lead to liver cirrhosis. Most commonly it affects female children and adolescents (4). There are three types of AIH: type 1, type 2, and seronegative AIH. Type 1 is a classic and most common form of the disease that is characterized by positivity for antinuclear antibodies (ANA) and anti-smooth muscle antibodies (ASMA). The illness usually occurs after the age of 10. Type $2 \mathrm{AIH}$ is characterized by the presence of anti LKM1 (liver-kidney microsomal type 1 antibody) and it mainly affects younger children. The disease is likely to present with severe clinical manifestations and it appears in a more progressive form. Seronegative AIH is characterized by the absence of antibodies. However, in such cases, the liver biopsy can reveal features compatible with autoimmune hepatitis. The standard treatment is based on administering corticosteroids and azathioprine $(5,6)$.

\section{CASE REPORT}

A nine-year-old girl was examined for the first time by a pediatrician due to fever, sore throat, and abdominal pain. The examination detected tonsillar hypertrophy and exudates, slightly swollen neck glands measuring up to $1 \mathrm{~cm}$, as well as liver and spleen pal- 
pable $1.5 \mathrm{~cm}$ below the costal margin. The serology testing showed positive EBV results: immunoglobulin $\mathrm{M}(\operatorname{IgM}) 1 / 250, \operatorname{IgG} 1 / 60$, transaminase AST 134 IU/L, ALT $459 \mathrm{IU} / \mathrm{L}$. Routine blood testing showed no signs of significant deviations. The patient underwent abdominal ultrasound imaging whereby no abnormalities were detected. The follow-up analysis performed two weeks later showed an increase in transaminase levels AST 599 IU/L, ALT 1,234 IU/L. Further analyses were conducted to exclude the potential diagnoses of Wilson disease (ceruloplasmin $29.4 \mathrm{mg} / \mathrm{dL}$ ) and Alpha-1 antitrypsin deficiency (Alpha-1 antitrypsin concentration $162 \mathrm{mg} / \mathrm{dL}$ ), and the obtained results showed no evidence of such diagnoses. However, significantly elevated levels of total IgG were detected, $21.2 \mathrm{~g} / \mathrm{L}$, which could be an important diagnostic marker for autoimmune disorders. Having established $\mathrm{AIH}$ as a potential diagnosis and after obtaining anti-LKM1 antibodies $<200 \mathrm{U} / \mathrm{ml}$, the patient underwent liver biopsy.

Percutaneous liver biopsy revealed mildly to significantly expanded portal zones. The lobular architecture was disturbed by the septa of connective tissue, portal tracts were somewhere joined with central veins and somewhere surrounded by small parenchymal nodules. Mild lymphocytic infiltration was detected as well as moderate interface hepatitis. Stage of severe fibrosis was diagnosed (Figure 1).

Prednisone and azathioprine therapy was initiated which led to the normalization of transaminase levels. After three months, prednisone was discontinued and allopurinol was introduced to reduce azathioprine. The patient then experienced epigastric pain and underwent a proximal gastrointestinal endoscopy examination. The obtained results were found in order. However, allopurinol therapy was discontinued whereas prednisone and azathioprine were reintroduced. Seven months later, clinical and lab remission was achieved. The patient was taken off prednisone and remained on azathioprine. However, four years after the diagnosis was established, new clinical manifestations arose such as muscle weakness of lower extremities, insecure walking, and falling. As proposed by the neurologist, electromyography was performed: motor nerve conduction velocity (MCV) for the peroneal nerve bilaterally and right tibial nerve, whereby distal latency, amplitude, and velocity were within normal range.

Sensory conduction velocity (SCV) examination of the sural nerve showed prolonged latency, normal amplitude, and slowed nerve conduction velocity. Electromyography (EMG) of the right leg rectus femoris muscle did not show pathological spontaneous activities, adenosine monophosphate (AMP) characteristics were found normal at muscle contraction, with

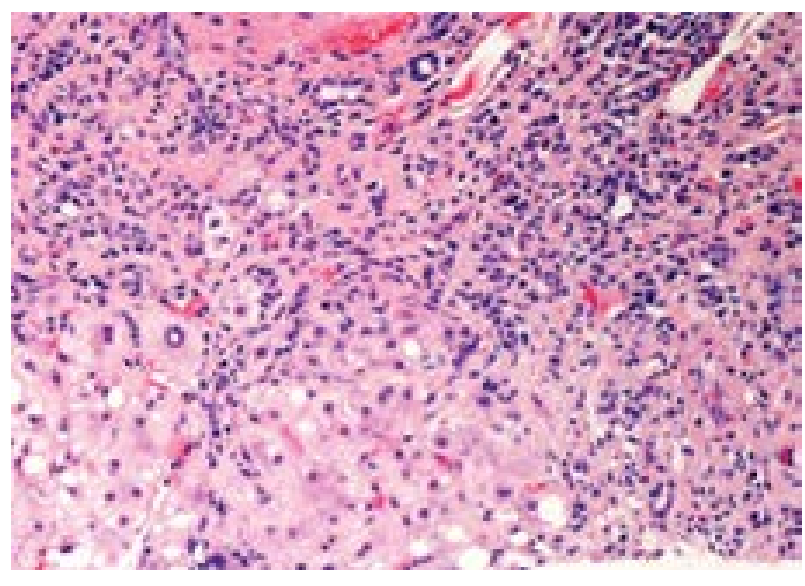

Figure 1. Interface hepatitis

some of them polyphasic. The obtained examination findings indicated the development of sensory neuropathy for the right sural nerve as well as potentials characteristic of a myopathic disorder in the examined muscle rectus femoris. At this stage, there was a clinical suspicion of corticosteroid-induced myopathy, but this diagnosis was not corroborated by the creatine kinase levels that were tested within the normal range. Additional three months of prednisone were prescribed as well as physical therapy. The combined treatment resulted in full recovery of standing and walking abilities. Currently, the girl reports no clinical symptoms. She is regularly attending high school and is taking azathioprine therapy.

\section{DISCUSSION}

EBV is a highly prevalent infectious trigger that affects a vast number of the worldwide population. Among others, it is the usual cause of infectious mononucleosis and is known for targeting B lymphocytes which can lead to lymphoid hyperplasia involving lymph nodes, liver, and spleen (2). Taking into consideration the disease onset of the case presented and its clinical manifestations, the initial suspicion of infectious mononucleosis was heavily grounded in the existing clinical research and case reports, as depicted in Dunmire et al. (2). Additionally, EBV can trigger fulminant infectious mononucleosis in some children due to the mutation of the X-chromosome gene responsible for encoding intracellular signaling protein, a mediator of signal transduction in lymphocyte activation (7). However, the subsequent clinical work-up redirected the diagnostic process towards the link between EBV and autoimmune hepatitis as its sequelae. Autoimmune hepatitis is a rare liver disease with an unknown etiology. Evidence in support of EBV in the pathogenesis of autoimmune hepatitis (AIH) is largely based around case reports noting the development of 
AIH following EBV infection, as was the case with our patient $(8,9)$.

The clinical presentation that included, elevated transaminase levels, interface hepatitis on histology, presence of LKM-1, liver inflammation, massive lymphocytic portal infiltrates extending into the surrounding lobules, accompanied by the patient's age and gender, all represent features of AIH type 2 pathogenesis. The most comprehensive analysis up to date focusing on the pediatric AIH as well as on the analysis of the treatment response has been described in the article from Porta et al. The clinical, histological, and laboratory findings of our patient coincide with the results presented in the article. The same combination treatment consisting of prednisone and azathioprine was administered to over $90 \%$ of the patients, whereby more than $76 \%$ of them achieved biochemical remission (10).

As for the muscle weakness of lower extremities, the conclusion has been reached that it was most likely atrophia ex inactivity due to prolonged bed rest,lack of physical activity, and excessive weight gain which the patient successfully managed to reverse.

Due to the highly variable clinical manifestations, it can be challenging to establish an AIH diagnosis. However, to achieve full remission, early detection and treatment can be of utmost importance. Conducting routine biochemical check-ups can help identify elevated ALT and AST levels, thus contributing to an early diagnosis. Steroids and azathioprine course of therapy requires administering a long-term treatment with strict adherence that can lead to a successful outcome and fully recovered patient.
Abbreviations
AIH - Autoimmune hepatitis
AMP - Adenosine monophosphate
ANA - Antinuclear antibodies
ASMA - Anti-smooth muscle antibodies
EMG - Electromyography
EBV - Epstein-Barr virus
LKM1 - Liver-kidney microsomal type 1 anti-
MCV - Motor nerve conduction velocity
SCV - Sensory conduction velocity body

Conflict of Interests: The authors declare that there are no conflicts of interest related to this article.

Funding: None

\section{Licensing}

This work is licensed under a Creative Commons Attribution 4.0 International (CC BY 4.0) License.

\title{
Sažetak
}

\section{INFEKTIVNA MONONUKLEOZA I AUTOIMUNI HEPATITIS}

\author{
Skoric Jasmina, Pavkovic Bojan \\ Health Centre "Dr Simo Milošević”, Belgrade, Serbia
}

Uvod: U radu je prikazan slučaj obolele devetogodišnje devojčice kod koje se bolest inicijalno manifestovala kao infektivna mononukleoza. Vrlo često $u$ pedijatrijskoj populaciji srećemo infektivnu mononukleozu i smatra se da je čak $50 \%$ dece do 5 godina prokuženo Epstein Barr virusom. Sumnja na infektivnu mononukleozu postoji uvek kada imamo dete sa uvećanim limfnim čvorovima vrata, temperaturom, otežanim i bolnim gutanjem. Međutim, usled daljih analiza u drugom mesecu nakon pojave prvih simptoma, posumnjano je na autoimuni poremećaj.

Rezultati: Na osnovu prikazanih simptoma, pored rutinskih analiza kao što su krvna slika, biohemijske analize, serologija na Epstein Barr virus, takođe je urađen ultrazvučni pregled abdomena, a određene su i vrednosti ceruloplazmina i alfa 1 antitripsina koje su bile uredne. Autoimuna priroda bolesti potvrđena je nalazom povišenih vrednosti ukupnog IgG, pozitivnim anti LKM antitelima i ,interface“ hepatitisom koji je utvrđen kao patoanatomski supstrat bioptata jetre.

Zaključak: U ovom radu prikazan je Epstein Barr kao neposredni uzrok autoimunog hepatitisa. Ovaj DNK virus poznat je po citopatogenom efektu na B limfocite. Otuda su se kao posledica infekcije ovim virusom javili uvećani limfni čvorovi, slezina i jetra. Sveukupan uticaj i na B limfocite i na jetru doveo je do stvaranja specifičnih antitela i infiltracije hepatičnih nodusa limfocitima.

Ključne reči: antitela, hepatitis, biopsija, Epstein Barr virus. 


\section{REFERENCES}

1. Womack J, Jimenez M. Common questions about infectious mononucleosis. Am Fam Physician, 2015; 15;91(6): 372-6.

2. Dunmire SK, Hogquist KA, Balfour HHJ. Infectious Mononucleosis. Curr Top Microbiol Immunol. 2015; 390(Pt 1): 211-40. doi: 10.1007/978-3-319-22822-8_9.

3. Peng H, Lim T, Nam J, Lee J. Autoimmune hepatitis following Epstein-Barr virus infection: a diagnostic dilemma. BMJ Case Rep. 2019; 12(7): e229615. doi: 10.1136/bcr-2019229615.

4. Alvarez F. Autoimmune hepatitis in children. J Pediatr (Rio J). 2019; 95(4): 382-4. doi: 10.1016/j.jped.2018.08.001

5. Della Corte C, Mosca A, Vania A, Alterio A, Alisi A, Nobili V. Pediatric liver diseases: current challenges and future perspectives. Expert Rev Gastroenterol Hepatol. 2016;10(2): 255-65. doi: 10.1586/17474124.2016.1129274.

\section{Correspondence to/Autor za korespondenciju} Jasmina Škorić

Health Centre "Dr Simo Milošević", Belgrade, Serbia Poručnika Spasića i Mašere 53, 11030 Belgrade

Cell phone: +381637111603

E-mail: jasmina.skoric1979@yahoo.com
6. Salih MM, Ibraheem MF, Nader KE. Etiology and clinical pattern of liver diseases in children. JFac Med Bagdad. 2018; 60(2): 76-9.doi: 10.32007/jfacmedbagdad.6028.

7. Houldcroft CJ, Kellam P. Host genetics of EpsteinBarr virus infection, latency, and disease. Rev Med Virol. 2015 Mar; 25(2): 71-84. doi: 10.1002/rmv.1816.

8. Liberal R, Vergani D, Mieli-Vergani G. Update on autoimmune hepatitis. J Clin Transl Hepatol. 2015; 3(1): 42-52. doi: 10.14218/JCTH.2014.00032.

9. Rigopoulou EI, Smyk DS, Matthews CE, Billinis C, Burroughs AK, Lenzi M, et al. Epstein-barr virus as a trigger of autoimmune liver diseases. Adv Virol. 2012; 2012: 987471. doi: 10.1155/2012/987471.

10. Porta G, Carvalho E, Santos J, Gama J, Borges CV, Seixas RBPM, et al. Autoimmune hepatitis in 828 Brazilian children and adolescents: clinical and laboratory findings, histological profile, treatments, and outcomes. J Pediatr (Rio J). 2019; 95(4): 419-27. doi: 10.1016/j.jped.2018.04.007. 